\title{
Internal Control System Analysis of Cash Receiving in Medan City Market Regional Companies
}

\author{
Hartati Situmorang \\ Department of Accounting, University of North Sumatra, Indonesia
}

\begin{tabular}{|c|c|}
\hline ARTICLE INFO & ABSTRACT \\
\hline Article history: & \multirow{4}{*}{$\begin{array}{l}\text { The purpose of this study was to determine how the policy } \\
\text { implementation of the internal control system in PD. Market and to } \\
\text { determine whether the application of the system of internal contro } \\
\text { over cash receipts in the PD Pasar is implemented properly. Methoc } \\
\text { analyze the data conducted with the descriptive method that is } \\
\text { collect the, process and interpretive data obtained so that can give } \\
\text { the clear picture hit the accurate ciecumstance and give the } \\
\text { boldness for trouble-shooting which is in facing. Writer have } \\
\text { conducted the analysis of concerning organization chart, procedure } \\
\text { and system of acceptance of cash of at On PD Pasar Kota Medan } \\
\text { and get some conclusion that is in principle On PD Pasar Kota } \\
\text { Medan have conducted the system of internal control of acceptance } \\
\text { of cash of applied according. }\end{array}$} \\
\hline $\begin{array}{r}\text { Received Jan 07, } 2022 \\
\text { Revised Jan 27, } 2022 \\
\text { Accepted Feb 25, } 2022\end{array}$ & \\
\hline & \\
\hline $\begin{array}{r}\text { System Internal Control; } \\
\text { Acceptance Cash; } \\
\text { Cash Receiving. }\end{array}$ & \\
\hline
\end{tabular}

This is an open access article under the CC BY-NC license.

\section{Corresponding Author:}

Hartati Situmorang,

Department of Accounting,

University Of North Sumatara,

Jl. Dr. Mansur No. 9 Padang Bulan, Kec. Medan Baru, Kota Medan 20222, Indonesia

Email: hartatisitumorang@gmail.com

\section{INTRODUCTION}

The renewal of regional financial management in this era of regional autonomy is marked by very basic changes, starting from the budgeting system, treasury to the accountability of financial statements. Prior to the implementation of regional autonomy, the accountability for regional financial reports that had to be prepared by the Regional Government was only in the form of a Budget Calculation Report and a Memorandum of Accounts and the system used to produce these reports was the MAKUDA (Regional Financial Administration Manual) which has been in effect since 1981.

Since the introduction of regional autonomy, the financial accountability reports that must be made by the Regional Head are in the form of a Budget Calculation Report, Calculation Note, Cash Flow Report and Regional Balance. The obligation to submit regional financial reports has been in effect since January 1, 2001, but until now, local governments still do not have government accounting standards as a reference in developing their regional financial accounting systems.

Cash is recognized at the nominal value of cash or cash equivalent, as well as checking accounts at banks that are not restricted in use. Changes in cash are influenced by two activities, namely: cash receipts and disbursements. Cash receipts include transactions that result in an increase in cash balances and/or bank accounts belonging to regional government entities, both from cash income, receivable receipts, transfer receipts, loan receipts, and other receipts.

Cash is the most liquid among other asset components, so cash can be used immediately and is very vulnerable to misuse and fraud. These characteristics make cash often misused and an object of fraud which will eventually disrupt the stability of the company and will threaten the 
survival of the company, it is very important to make a protection against cash in the company's activities.

The Regional Market Company (PD Pasar) of Medan City is one of the Regional Owned Enterprises managed by the Medan City Government in accordance with Regional Regulation No. 8 of 2001 concerning the establishment of the Medan City Market Area which is engaged in market arrangement. The office that is used as the office of PD. Medan City Market, Jl. New Razak No. 1A Petisah Market Lt. III Medan. The Regional Market Company of Medan City has 56 markets in Medan City located in 22 sub-districts with an area of $172,510.35 \mathrm{~m} 2$ with a total of 8,795 stalls with 8,409 stands and 63 shops with a total of $\pm 22,922$ traders. Where has a vision and mission and goals to be achieved.

As a Regional Owned Enterprise, the Regional Company must have cash. To protect cash and ensure the accuracy of accounting records for cash receipts. Therefore, PD Pasar Medan requires an effective internal control system for cash receipts. Internal control over cash receipts is very important for the company.

\section{RESEARCH METHOD}

The research carried out is case study research, where the author collects research data obtained from the object of research and other literatures, then describes in detail to find out the research problems and look for problems.

\subsection{Analysis Techniques}

Data analysis is a process of systematically searching and compiling data that has been obtained in the field, so that later it can be easily understood and informed to others (Sugiyono, 2008). The data analysis method in this study uses a descriptive qualitative approach to a qualitative approach or non-statistical analysis that is describing or describing a phenomenon as it is. Data analysis was carried out based on the data that had been obtained in the field. The data obtained are analyzed and evaluated by comparing with existing theories to find possible problems with the system owned by the company. The steps taken in analyzing the data are:

a. Analyzing the existing organizational structure at the Medan City Market Regional Company.

b. Analyzing the internal control system for cash receipts at the Medan City Market Regional Company, including: sources, procedures, functions, and documents used as well as related information. The results of the analysis and evaluation will be drawn as conclusions to answer the problems that arise in the internal control system for cash receipts at the Medan City Market Regional Company.

\section{RESULTS AND DISCUSSIONS}

\subsection{Policy implementation}

a. Aspects of human resources (HR).

The existence of Human Resources at PD Pasar Kota Medan really needs to be adjusted to the current developing conditions. Placement of employees in accordance with the expertise/discipline with the field of work. The number of employees consists of Directors, Employees, and BHL Cleaning. The number of employees in the past 5 (five) years are:

Table 1. Number of Employees

\begin{tabular}{cc}
\hline Year & Amount \\
\hline 2008 & 759 \\
2009 & 756 \\
2010 & 729 \\
2011 & 723 \\
2012 & 708 \\
\hline
\end{tabular}

\section{b. Customer aspect}

Market traders are one of the most important elements in determining the performance of PD. Medan City Market. Market traders are the main customers and are the main targets that must be 
considered. This market trader is influential in the income for PD. Medan City Market. The position of the number of traders 2008-2012.

Table 2. Number of Traders in PD Pasar Medan 2008-2012

\begin{tabular}{cccccc}
\hline Type & \multicolumn{5}{c}{ Number of Merchants } \\
\hline Year & 2008 & 2009 & 2010 & 2011 & 2012 \\
Kiosk & 8090 & 8108 & 7994 & 8983 & 8795 \\
Stand & 8765 & 8753 & 9436 & 8977 & 8409 \\
Informal Traders & 893 & 913 & 821 & 4589 & 987 \\
\hline
\end{tabular}

\subsection{Types of cash receipts}

The following are matters relating to cash receipts at PD Pasar Medan:

\section{a. Regional revenue sources}

Cash receipts that are recorded as income at PD Pasar Medan are obtained from:

1) Monthly bill at the place of sale

2) Market infrastructure

3) Cleanliness

4) Ticket sales

5) Permission/Certificate

6) Cooperation from third parties

\subsection{Analysis and evaluation of the company's organizational structure}

The organizational structure of regional financial management at PD Pasar Kota Medan is in the form of a line, where superiors have a number of subordinates and are directly responsible for their duties to their superiors. This facilitates coordination between superiors and subordinates and facilitates supervision by superiors to subordinates.

The organizational structure separates functional responsibilities clearly. The organizational structure is a framework for the division of functional responsibilities to organizational units formed to carry out the company's main activities. The organizational structure is expected to reflect a clear division of authority and responsibility as well as a separation of duties and functions to prevent fraud.

The organizational structure at PD Pasar Kota Medan has reflected the existence of a clear division of authority and responsibility as well as the separation of the authorization function from the function that handles cash. The authorization function is carried out by the budgetary sector, while the technical function in the field of regional financial management is all activities that include planning, implementation, administration, reporting, accountability, and regional financial supervisors. In the organizational structure of internal control cash receipts PD Pasar Kota Medan is led by the Mayor.

\subsection{Analysis and evaluation of the implementation of internal control}

Based on the results of the author's research and after being compared with the theoretical basis contained in the previous chapter, the element of internal control in the company is adequate.

\section{a. Organizational structure}

The organizational structure of PD Pasar Kota Medan as previously described is in the form of a line. Each head of the organizational unit is required to implement an internal control system in their respective environments that allows the implementation of a cross-testing mechanism. Each organizational unit leader is also responsible for leading, coordinating, supervising their respective subordinates and providing guidance and instructions for the implementation of the duties of their subordinates.

\section{b. A capable employee}

The appointment of structural officers at PD Psar Medan City is carried out based on the applicable laws and regulations. Mayors in appointing or filling structural position formations may use competency tests, fit and proper tests and/or various other mechanisms as one of the considerations for obtaining quality positions and having loyalty to the mayor. 


\section{c. Authority system and recording procedure}

Receipt receipts can be used at the cashier to receive some money from the operational department. First, the receipt is signed by the operational division officer and affixed with a paid stamp as proof of receipt of invoices for mandatory contributions and contributions. From the receipt, the operational division makes a list of receipts and proof of cash deposit signed by officers and officers of the operational division which will be given to the cashier. For the operational control system, make an expedition book as a document for depositing money to the cashier which must be signed by the cashier.

By using the list of receipts and receipts as proof of comparison with the cashier in calculating the amount of money received. After performing a physical count of money, the cashier enters the merchant's data. Proof of incoming cash signed by the accounting / finance, cash sub-section and operational officers. Proof of Cash Incoming (BKM) can be used as a basis for recording by the accounting department.

\section{d. Healthy practice}

In PD Pasar healthy practice by:

1) Use of printed sequential forms. In cash receipts, the principal form uses a printed serial number. This can be seen in the payment receipt which uses a printed serial number.

2) Every day the cash section provides a report to the bookkeeping/accounting section on how much cash came in that day and provides cash receipts to the accounting section.

3) Cash deposits received today will be deposited to the Bank on the same day.

4) There is staff examiner internal which in the company is called the Internal Supervisory Staff (SPI)

5) During an employee's leave, the position of the employee concerned is temporarily replaced by another position.

6) Job rotation is held regularly in order to avoid collusion among other employees.

In order to improve the performance of transparency and accountability of regional financial managers, the Mayor regulates and implements an internal control system within the regional government he leads. Internal control is a process designed to provide adequate assurance to the district as reflected in the reliability of financial reports, the efficiency and effectiveness of implementing programs and activities as well as compliance with laws and regulations. The following criteria must at least be met in the context of internal control:

1) Creating a healthy control environment.. These are actions, policies and procedures that reflect the overall attitude of the leadership and personnel in PD Pasar Medan City towards controlling cash receipts to the overall condition of the organization. Conducted risk assessment. Carrying out risk assessments, the Mayor and the Head of the Market always pay attention to the possibilities in changing situations and conditions that cause obstacles in carrying out daily operational activities. The Market Head always coordinates to deal with possible risks that occur.

2) Implementation of control activities. Carrying out internal control in the regions is the Mayor and external supervision by the BPK.

3) Implementation of information and communication systems. In the implementation of the internal control system on cash receipts requires a systematic procedure and in accordance with applicable laws.

4) Implementation of control monitoring activities. In monitoring the implementation of the internal control structure within PD Pasar Medan, the head of the market and the head of the field always pay attention to information and inputs from related parties, either directly or indirectly on the procedures for implementing cash receipts management.

\subsection{Analysis and evaluation of internal control cash receipts}

The internal cash control system carried out by PD Pasar Kota Medan is:

a. The use of a printed serial form, which is contained in the payment receipt using a printed serial number.

b. Responsibilities assigned specifically to handling cash receipts.

c. Separate handling and recording of cash receipts.

d. Every day the cash section provides a report to the accounting department about how much 
cash came in that day and provides cash receipts to the accounting department.

e. All cash received today will be deposited to the Bank on the same day.

f. There is an internal audit staff within the company called the Internal Supervisory Staff (SPI) and the party that carries out operational inspections at PD Pasar Medan City is the Financial Supervisory Agency (BPK).

\section{CONCLUSION}

The existence of the organizational structure of PD Pasar Kota Medan already illustrates the separation of functions, authorities of each section. Each section is responsible for their respective fields and must be able to be accountable to their respective leaders. The party or official who conducts operational checks on PD Pasar Kota Medan is the Financial Supervisory Agency (BPK).

The existence of adequate documents and evidence of transactions such as: cash evidence, bank evidence, memorial evidence, journal entry evidence consisting of bookkeeping, and supporting evidence consisting of receipts, bank deposit evidence, cash register, where the document is affixed with a signature authorized official. As for the procedures carried out at PD Pasar Kota Medan in cash receipts, there are related functions, documents used. The cash receipt procedures carried out by PD Pasar Kota Medan are basically adequate because they are based on evidence in each cash receipt transaction and there is a separation of cash and accounting functions. There is an authorization from the authorized party in receiving cash.

\section{REFERENCES}

Arikunto, Suharsimi, 2006. Prosedur Penelitian, PT Rineka Cipta, Jakarta. Bastian, Indra, 2006. Sistem Akuntansi Sektor Publik, Edisi Tujuh, Jilid I, Erlangga, Jakarta.

Halim, Abdul, 2007. Akuntansi Keuangan Daerah, Edisi Ketiga, Salemba Empat, Jakarta.

Haryono, Jusup, 2001. Auditing (pengauditan), Bagian penerbitan Sekolah Tinggi Ilmu Ekonomi YKPN, Yogyakarta.

Ikatan Akuntan Indonesia, 2007. Standar Akuntansi Keuangan, Salemba Empat, Jakarta.

James, A. Hall, 2011. Sistem Informasi Akuntansi, Edisi Empat, Salemba Empat, Jakarta.

Mardiasmo, 2002. Akuntansi Sektor Publik, Andi Yogyakarta, Yogyakarta. Marshall, Romney B, dan Paul John Steinbart, 2005. Sistem Informasi Akuntansi, Buku I, Edisi Sembilan, Terjemahan Salemba Empat, Jakarta.

Mulyadi, 2001. Sistem Akuntansi, Edisi Ketiga, Cetakan Ketiga, Salemba Empat, Jakarta.

Nazir, Moh, 2002. Metode Penelitian, Ghalia Indonesia, Jakarta. Sugiyono, 2010. Metode Penelitian Bisnis, Alfabeta, Bandung.

Warren, Carl S. dkk, 2005. Pengantar Akuntansi, Edisi 21, Terjemahan Salemba Empat, Jakarta.

William,C. Boynton,dkk, 2003. Accounting - Modern Auditing, Edisi Ketujuh. Erlangga, Jakarta.

Zaki, Baridwan, 1993. Sistem Akuntansi Penyusunan Prosedur dan Metode, BPFE, Yogyakarta. 